対し, Lorenz 法と R. B. 法との併用療法は, 整復開 始時期と固定期間に留意して行えば，良い治療成績が 得られるものと考える.

（宮城教授の御校閲に感謝する）

\section{文献}

1) Chuinard, E. G., : J. Bone Jt Surg., 45-A 1397, 1963.

2）岩永安弘：久留米医学会雑誌. 32,239 , 昭 44 .

3) Platou, E.: J. Bone Jt Surg., 35-A, 48, 1953.

4）坂口 亮, 他：関東整災誌. 6,23 , 昭 50 .

5）山田勝久：日整会誌. 37: $511,1963$.

6）矢野祜二：西日本整災誌. $24: 475$, 昭 50 .

啠問州大学松尾隆

比較的似かよった考え方で治療されており興味深く

見せていただいた。

Lorenz 法に代表されるいわりる開排位固定につい

ては多くの批判があるが本当に開排位固定に問題があ
るのだろうかと思う事がある。

われわれも時に整復の後開排位にキャストで整復が 確実に行なわれているという条件で固定する事もある がペルテス様変化が殆んど見られない点，一概に開排 位固定が悪いという考え方には，賛成しがたい。

しかしながら先生は全麻化の整復キャスト固定を多 用しておられるが，一率のての様な考え方には，ペル テス樣変化等ひき抢てす原因が内蔵している感じで一 般的にすす女られないと思います。いかがでしょう か.

回答娍生会福岡病院 岩永 安弘

Lorenz 法による骨頭核変化の要因の一つつに, 整復 開始時に問題があると思う.

特に, 6 力月未満の症例に発生頻度が高い反面, 6 〜15 カ月目に整復されたものは治療成績も良かった。 観血的整復にても満足出来る成績が得られない今日, 本法は試みるべき治療法と考える。

\title{
先天性股関節脱臼治療後の内反股を 併う大転子高位の発生過程
}

山口大学医学部整形外科学教室（指導：服部奨教授）

小田 清 彦・伊 達 洋次郎
今 釜 哲 男・宮 本 龍 彦

\section{Retrospective Studies on a Coxa Vara with a Short Neck and a Long Greater Trochanter Occurred after the Treatment of Congenital Dislocation of the Hip Joint}

By

\author{
K. Oda, Y. Date, T. Imagama and T. Miyamoto \\ Department of Orthopedic Surgery, Yamaguchi University School of \\ Medicine, Ube-Shi. (Director: Prof. S. Hattori)
}

The author noticed a deformity of the upper femoral region which occurred after the closed treatment of congenital dislocation of the hip joint and attempted to elucidate this cause by clinical observation.

Of 6 cases with this deformity, the process of its development was analysed by persuading the course of treatment and radiographic changes.

It was found out that most of the cases had been treated before three months of age They were immobilized in frog-leg plaster cast following closed reduction. 
On the radiographs all of them showed not only the involvement of epiphysis and physis of the femoral head, but also metaphysis.

In comparison with normal cases, all of them showed the growing disturbance of the femoral neck.

当教室で最近経験した先天性股関節脱臼治療後に発 生した内反股を併った 大転子高位症例は 14 例である が，乙れら症例の内，逆行性にその経過の明らかな症 例は， 6 例 10 肢であった。 そして，それらの症例で は一定の発生過程をとっているように思われるので, 臨床症状, 代表的症例の紹介, 乙れら症例の発育経過 と正常大腿骨上部の種々の計測值との比較を行ない報 告する.

症例の最終彭察時年令は, 表の如く, 5 17才で全 例が女子であり両側脱臼 4 例, 片側脱目 2 例である.

治療開始年月日は, 生後 8 力月で治療を始めた 1 例 を除き，他は全例 3 力月以内での治療開始である．骨 頭に対する暴力も骨頭が幼弱なほど大きな障害をもた らす事はすでに，先人の指摘するとてろであるが，， ての事が大きく関係していると考える.

初期治療は, 1 例か漸性装具汃ら硬性装具による治 療施行例である以外は，他の全例が徒手整復，ローレ ンツ第 1 肢位での ギプス固定, 硬性装具装着例であ る. 生後 3 力月以内の乳児に対する治療として整復, ギプス固定の弊害は述べるまでもない事であるが，今 日でもまだ経験ある整形外科医のものでも行なわれて おり，嘆かわしい事である.

脚長差は, 片側例では 10 才前後で $10 \mathrm{~mm}$ 程度のも
のが現われているが，両側例では当然の事ながら頸部 短縮や骨頭障害の程度の差によって見られる場合もあ る.

大転子高位があると，股関節の外転制限が見られる が，てれが大転子高位によって起ったものか否かを知 る目的で，股関節外転角度の測定值の推移を調べた。 初期治療終了後, 徐々に外転制限力強くなっていく場 合は，他の因子も関係する場合もあろうが，大転子高 位が大きく関係しているのではないかと考える。

多くの症例に Trendelenburg 症候も発生し跛行も 多数に現われている.

症例 1 . 写真 1 . 胎生 8 力月で帝王切開による出 産, 出生時体重 $1650 \mathrm{gr}$, 生後 8 力月より両先天股脱 にて, 整復, ギプス固定, 硬性装具装着を受け，1才 4 力月頃，両股関節は骨頭核の発現を見ていない４ 才時に両側 Epiphysis のペルテス様変化と Physis の乱れ, Metaphysis で両側の変形, 硬化像, 右側の 透明柴の発現と，大腿骨頸部の短縮内反の所見を認 め, 17 才時，両大腿骨頸部の著明な内反股と右側に $10 \mathrm{~mm}$, 左側に $11 \mathrm{~mm}$ の大転子高位を認める.

症例 2 . 写真 2 . 生後 3 力月目に両先天股脱にて整 復, ギプス固定, 硬性装具装着を受ける. 6 才時, 両 大腿骨頭の Epiphysis にペルテス様変化, Physis の

\begin{tabular}{|c|c|c|c|c|c|c|c|c|c|c|c|}
\hline 症 例 & 性 & 年令 & 患側 & $\begin{array}{l}\text { 治 療 } \\
\text { 開始月 }\end{array}$ & 初 & 期 治 療 & 脚長差 & 股 S & 転 & $\begin{array}{l}\text { Trende- } \\
\text { lenburg }\end{array}$ & 跛 行 \\
\hline & 우 & 17 & 両 & 8 力月 & ギ固 石 & 硬性装具 & 0 & $\begin{array}{l}\text { 右 } \\
\text { 左 }\end{array}$ & $\begin{array}{l}30^{\circ} \\
30^{\circ}\end{array}$ & \pm & \pm \\
\hline & 우 & 12 & 両 & 3 力月 & " & " & 0.5 & $\begin{array}{l}\text { 右 } \\
\text { 左 }\end{array}$ & $\begin{array}{l}25^{\circ} \\
25^{\circ}\end{array}$ & $\overline{+}$ & + \\
\hline & 우 & 11 & 左 & 2 力月 & 軟性装自 & 具 硬性装具 & 1 & $\begin{array}{l}\text { 右 } \\
\text { 左 }\end{array}$ & $\begin{array}{l}35^{\circ} \\
30^{\circ}\end{array}$ & $\bar{t}$ & + \\
\hline & 우 & 9 & 両 & 3 力月 & ギ固 石 & 硬性装具 & 0 & $\begin{array}{l}\text { 右 } \\
\text { 左 }\end{array}$ & $\begin{array}{l}30^{\circ} \\
30^{\circ}\end{array}$ & $\overline{-}$ & - \\
\hline & 우 & 9 & 右 & 2 力月 & " & " & 1 & $\begin{array}{l}\text { 右 } \\
\text { 左 }\end{array}$ & $\begin{array}{l}25^{\circ} \\
70^{\circ}\end{array}$ & \pm & + \\
\hline & 우 & 5 & 両 & 3 力月 & " & " & 0 & & & $=$ & - \\
\hline
\end{tabular}




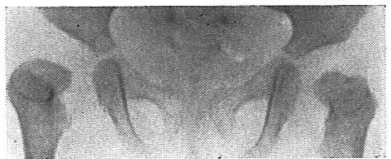

1 才 4 力月
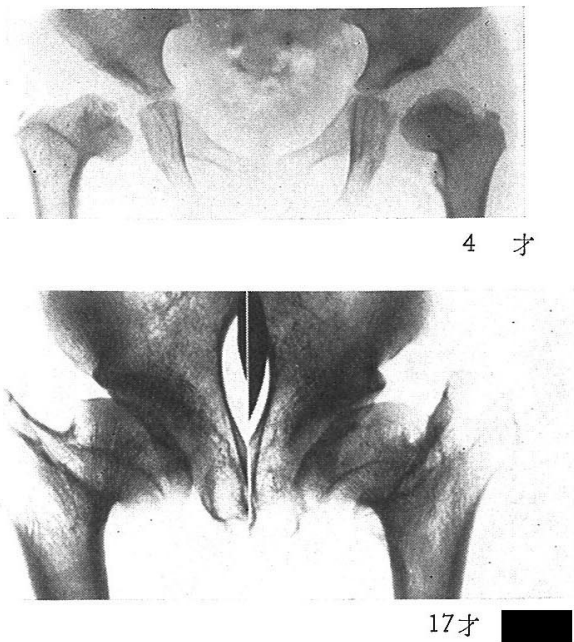

写真 1
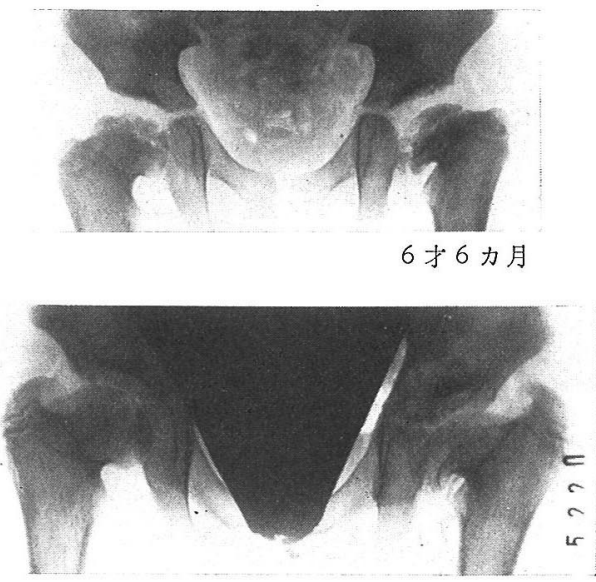

$11 才$

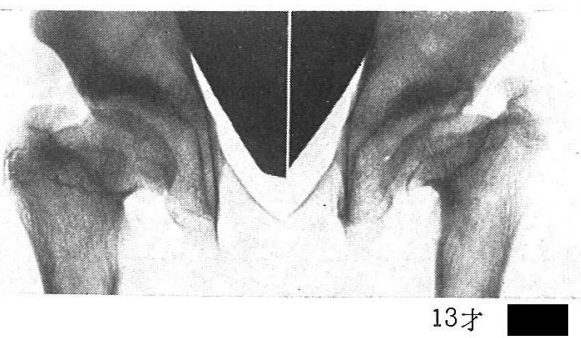

写真 2

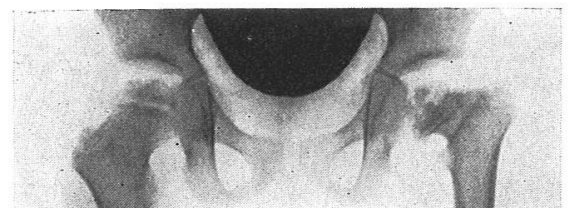

3 才 6 力月
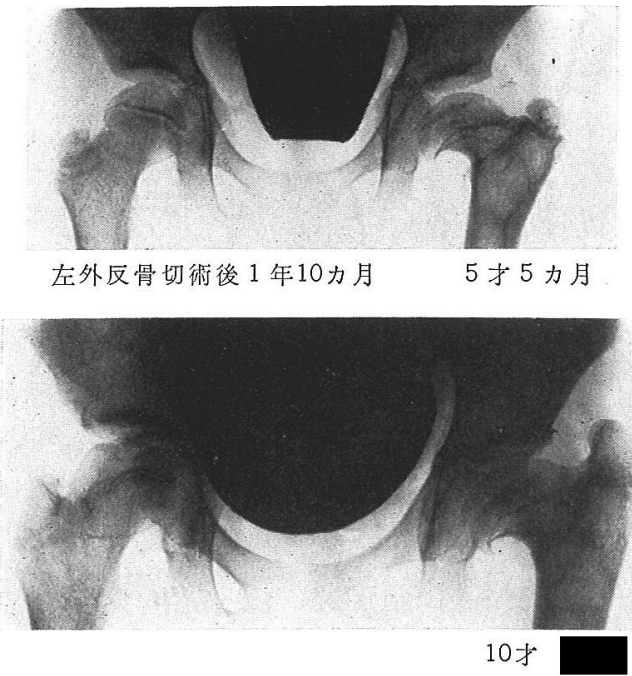

写真 3

乱れ, Metaphysis の変形, 大腿骨頸部短縮, 左大転 子高位を認める.11 才時両側の Physis は閉鎖し， 闭側頸部は内反股を呈し, 右側に $3 \mathrm{~mm}$, 左側に 17 $\mathrm{mm}$ の大転子高位を認める。

症例 3 . 写真 3 . 生後 2 力月目より左先天股脱にて 軟性装具，硬性装具により治療されたが，3才時左股 関節に内反股と左大腿骨骨頭の Epiphysis そペルテ 又様変化, Physis の乱狄, Metaphysis の骨硬化， 分節化を認め，大転子は大腿骨骨頭頂と同じ高さでこ の時期に处反減揄骨切り術を施行する．10才時左大腿 学頭の Physis は閉鎖し, 内反股は著明で $15 \mathrm{~mm} の$ 大転子高位を認める。

大転子高位をきたした症例の大腿骨上部のA B C D E值と正常者のそれを比較した（図1）.

正常者のA B C D E 值の測定は，1才より15才ま での各年令で，おのおのの年命の測定者は 6〜14 人で 計 125 人に施行した。

正常者で大転子骨端核の発現は3〜 7才の間で見ら れ，発現前の場合は，大転子骨端核の発現が予想され る部位より測定した。 


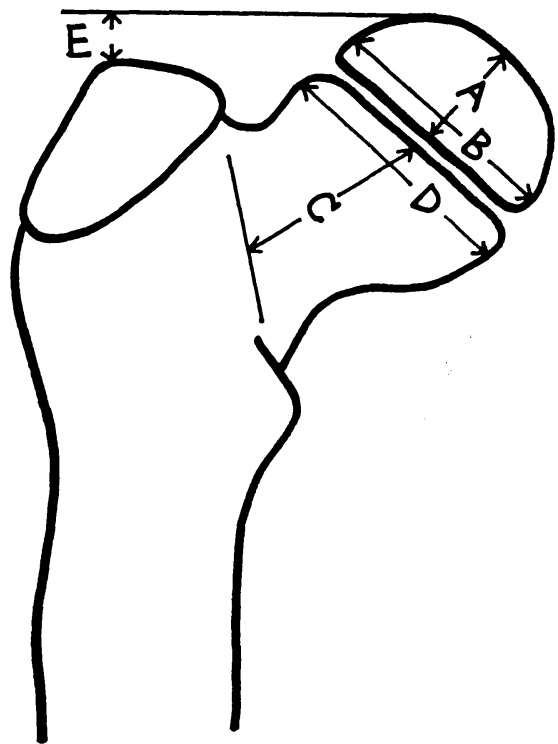

図 1

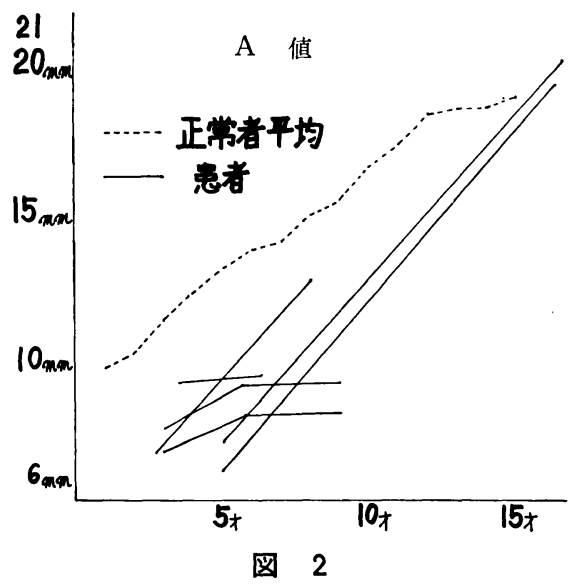

\section{Epiphysis}

正常者において, Epiphysis は生後 10 力月以前に 発現するが，Epiphysis の発現が遅れる例が多い. 全例において，ある時期にペルテス椂変化を認める. 縦方向（A・図 2）光の成長障害が正常例に比較すれ ばかなり強いが，横径（B・図３）は障害がないよう である.

\section{Physis}

当初は水平位に近いが成長につれて垂直位に近くな

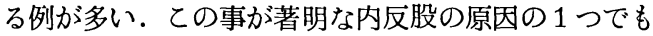
あろうと思われる．正常例または正常側に比較して早
B 值

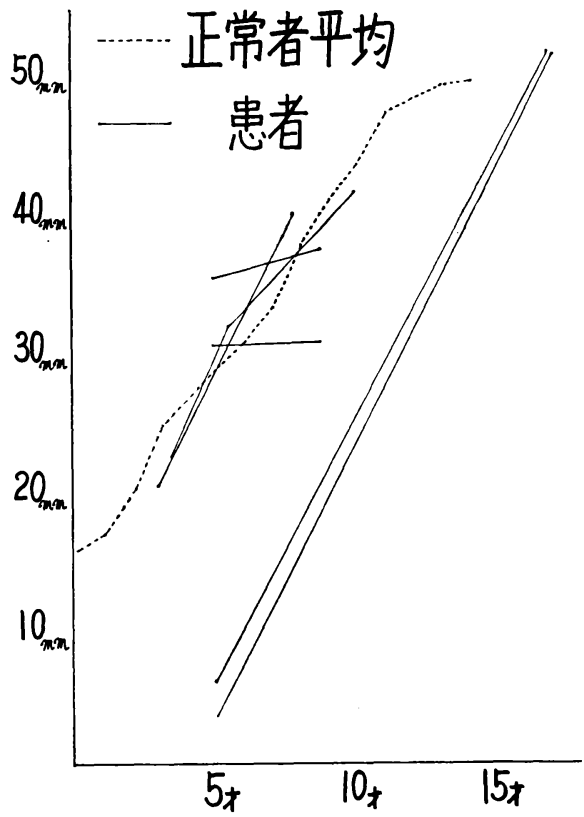

図 3

C 值

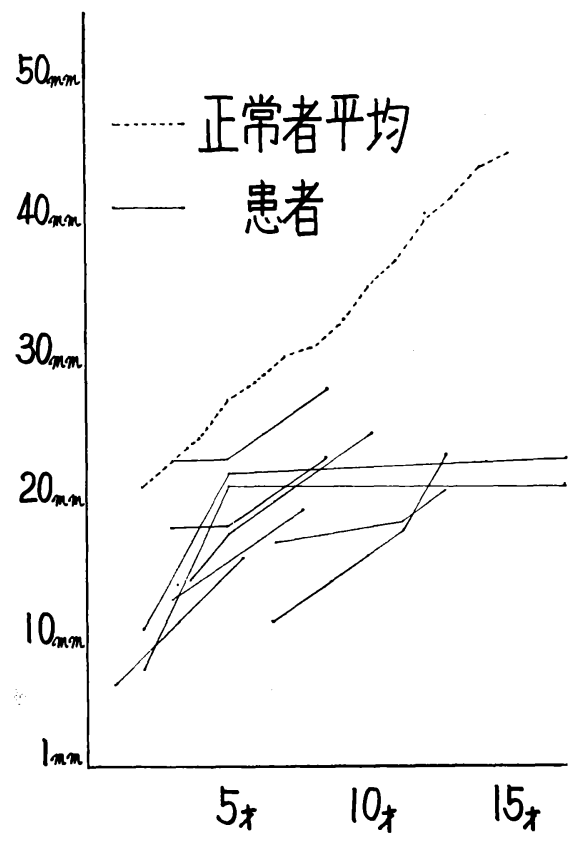

図 4 
D 值

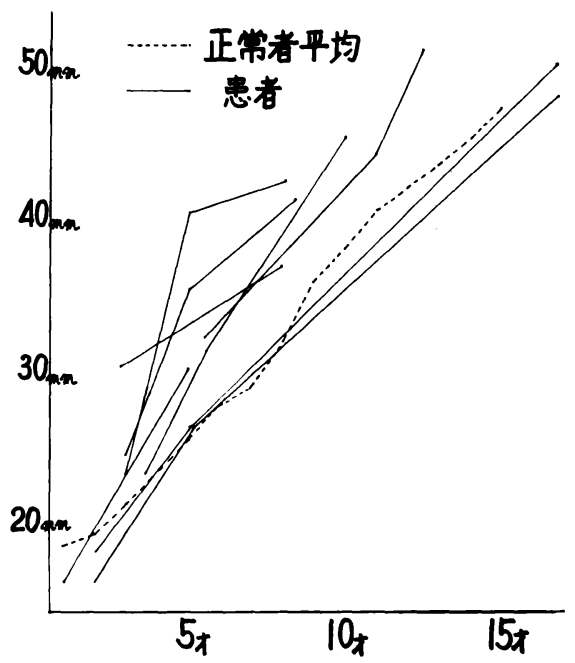

図 5

期より閉鎖の傾向が見られる.

\section{Metaphysis}

Epiphysis にペルテス様変化の見られる時期に Metaphysisにも骨硬化や透明巣などが見られる．夹 際には前捻角が関係して，単純前後面のフィルム上で の計測では，問題があるが，傾向としては，大腿骨頸 部の長軸方向（C・図 4) の障害は著しいようであ る. Metaphysis の横径（D・図 5 ）には，成長促進 の傾向が見られる.

\section{大転子}

正常例では，大腿骨頭頂は大転子より約 $20 \mathrm{~mm}$ 程 度高位にある（図6）が，てのような症例では，4〜 5 才頃より大転子は大腿骨頭頂より高位となり始め; 10 才前後で $15 \mathrm{~mm}$ の高位の認められる場合もある。

以上より, 先天股脱治療後の内反股を併った大転内 高位は，日萺形成不全などによる薀側の因子や，大 転子の Physis に対する筋性張力等が影響しているて とも想像されるが，主として初期治療中に加えられた 大腿骨頭の Eiphysis, Physis, Metaphysis の障害 により，てれらの部位での長蟿方向への成長障害が起 るにもかかわらず，大転子の骨端核が普通に発育する ことによる発育上のアンバランスによる所見であるよ 解釈出来る（服部教授の御校閲に感謝する.）

E 值

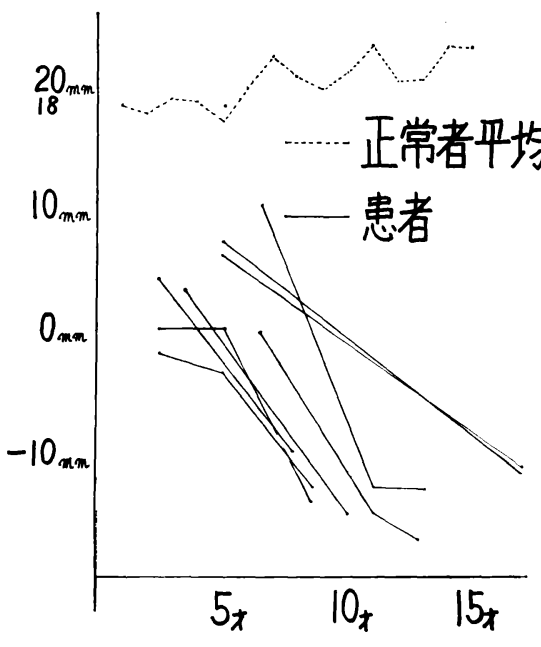

図 6

文

献

1）石垣 真：日整会誌, 40：1229-1246, 1966.

2）岡田 靖：日整会誌. 44:117-133, 1970.

3) 松永隆信ほか：中部整災誌. $18: 748-754$, 1975.

4) A. Langenskiöld et al.: Acta orthop. Scandinav., 38: 199-219, 1967.

5) L. E. Laurent: Acta orthop. Scandinav., 28: 255-261, 1959.

6) L. Jani: Arch. orthop. Unfall-Chir. 66: 127-132, 1969.

\section{質 問長崎大 岩崎 勝郎} 大転子高位の発生原因に関して，血管性によるもの と考えておられるか。また，発育に関与する軟骨細胞 の Pressure necrosis などを考えておられるか.

\section{解 答出口大学 小田 清彦}

先天性股関節脱臼の幼弱時期における骨頭変形の主 因子は骨頭核に対する血流障害であろうと考えていま す.

Epiphysis の縦方向えの障害が骨頭の扁平化とも たらし, Physis や Metaphysis 部での障害が大腿骨 頸部の縦方向えの成長障害すなわち大腿骨頸部短縮を もたらすと考えます。 